\title{
Pendampingan Penerapan Sistem Minapadi Dalam Upaya Peningkatan Pendapatan Kelompok Tani Di Desa Guci Kabupaten Lamongan
}

\author{
Nurul Badriyah, Hidayat Tauhid, Yunni Rusmawati DJ \\ Program Studi Megister Manajemen, Universitas Islam Lamongan, Indonesia \\ Email corresponding authors: nurulbadriyah@unisla.ac.id
}

\begin{abstract}
ABSTRAK
Perikanan budidaya saat ini menjadi tumpuan penting dalam menompang perekonoian masyarakat Indonesia, terutama bagi masyarakat yang memperoleh pendapatan dari budi daya ikan. Hal tersebut yang dialami oleh sebagian masyarakat di kabupaten lamongan khususnya di Desa Guci. Akan tetapi hasil budi daya ikan yang yang diperolah masih bersifat fluktuatif, hal ini disebabkan banyak faktor terutama pengetahuan warga tentang ilmu budi daya ikan yang masih dirasa kurang. Melihat dari luasnya lahan pertanian yang ada di Desa Guci serta banyaknya penduduk Desa Guci yang berprofesi sebagai petani, seharusnya potensi alam yang ada dalam hal ini lahan pertanian bisa diolah dengan semaksimal mungkin demi tercapainya kesejahteraan kelompok tani di Desa Guci. Akan tetapi selama ini masih kurangnya pengetahuan masyarakat Desa Guci terutama yang berprofesi sebagai petani memahami bagaimana cara pemanfaatan lahan yang ada. Karena lahan yang ada hampir seluruhnya hanya ditanami padi pada msim kemarau dan dibuat tambak ketika musim hujan telah tiba. ikan yang dibudidayakan di tambaknya pun terbatas jenisnya yakni udang, ikan bandeng, ikan mujair dan kadang kala ikan lele. Tahap sosialisasi dilaksanakan di tempat mitra yaitu Kelompok Tani sebagai penghasil beras organik di Desa Guci Kabupaten Lamongan. Sosialisasi tersebut akan dilakukan secara intensif kepada beliau mulai dari instalasi alat, pengoperasian alat dan pemeliharaan alat. Selain itu strategi manajemen pemasaran juga disosialisasikan kepada Kelompok Tani mengingat beras organik akan dipasarkan secara meluas. Setelah kegiatan tersebut dilaksanakan, perlu diadakan monitoring untuk memantau kemajuan dari kegiatan yang telah dilakukan baik dari segi teknologi pengemasan maupun pemasaran.
\end{abstract}

Kata Kunci : Kelompok Tani, Pendapatan, Sistem Minapadi

\section{PENDAHULUAN}

Indonesia merupakan salah satu negara yang sebagian besar penduduknya berprofesi sebagai petani. Indonesia juga merupakan Negara penghasil beras terbesar di dunia. Pada akhir tahun 2018, panen padi di Indonesia mencapai 56,54 juta Ton dan diproyeksi terjadi surplus produksi beras sekitar 2,85 juta ton. Salah satu Kota atau Kabupaten di Indonesia yang masyarakatnya sebagian besar petani adalah Kabupaten Lamongan. Pada akhir tahun 2017 penghasilan padi di Kabupaten Lamongan mencapai 924,933 ribu ton. Sedangkan pada akhir tahun 2018 produksi padi di Kabupaten Lmongan mengalami penurunan menjadi 924,21 ribu ton. Penurunan yang terjadi dipengarui oleh banyak faktor diantaranya yakni, serangan hama(tikus), dan kurangnya pasokan air yang disebabkan tingginya biaya untuk mengalirkan air dari tampat penampungan air ke area persawahan.

Strategi percontohan perikanan dan budidaya dilaksanakan melalui peningkatan produksi, produktivitas, dan daya saing yang berbasis ilmu pengetahuan melalui industrialisasi perikanan budidaya yang akan perankan menjadi upaya mendapatkan nilai tambah ganda yakni bidang pertanian dan perikanan. Dengan menerakpan sistem minapadi menjadi jalan uantuk meningkatkan produktivitas kelompok tani di Desa Guci baik dalam segi pertanian maupun perikanan. 
Budidaya minapadi adalah budidaya ikan dan padi dalam satu hamparan sawah. Minapadi dapat meningkatkan produktivitas lahan sawah karena selain tidak mengurangi hasil padi, juga dapat menghasilkan ikan. Budidaya minapadi dilakukan masyarakat sejak lama walaupun asih menggunakan teknologi sangat sederhana hanya sebatas pada kegiatan tahapan pendederan. Dengan usaha ini diharapkan dapat meningkatkan pendapatan kelompok tani di Desa Guci serta sebagai upaya untuk menghadapi permasalahan atau kendala yang dialami.

Tujuan dari Program Pengabdian Kepada Masyarakat, yaitu:

1. Untuk mengetahui potensi sistem minapadi dalam mengatasi masalah penanaman padi serta pembudidayaan ikan di kelompok tani Desa Guci.

2. Untuk mengetahui cara dalam menerapkan sistem minapadi mulai dari pernyiapan lahan, sampai pemanenan padi serta ikan di Desa Guci.

3. Untuk mengetahui cara dalam sistem minapadi dalam upaya peningkatan pendapatan kepada kelompok tani di Desa Guci

\section{GAMBARAN UMUM MASYARAKAT}

\section{Kondisi Kelompok Tani Desa Guci}

Desa Guci merupakan salah satu di Wilayah Kecamatan Karanggeneng dari 18 Desa, yang terletak di -7'0'3.42' LS , 112'18'28.77' dengan ketinggian 7 Mdpl. \pm 7 Km ke ibukota Kecamatan atau $\pm 26 \mathrm{Km}$ ke ibukota kabupaten. Desa Guci mempunyai wilayah seluas 149 Hektar, dengan lahan persawahannya seluas 98,9hektar sedangkan lebihnya adalah permukiman warga dan fasilitas umum.

Secara umum mata pencaharian warga masyarakat Desa Guci dapat teridentifikasi ke dalam beberapa bidang pencaharian seperti : Petani (42,00 \%), Buruh Tani $(9,13 \%)$, Pegawai Negeri Sipil (PNS) $(0,18 \%)$, Karyawan Swasta $(0,91 \%)$, Perdagangan $(1,22$, Pensiunan $(0,12$ $\%)$, Transportasi, Buruh Harian Lepas, Guru $(2,43 \%)$, Wiraswasta $(2,43 \%)$ yang secara langsung maupun tidak langsung telah memberikan konstribusi terhadap perkembangan perekonomian masyarakat Desa Guci

Jika dilihat dari hasil panen yang diperoleh kelompok tani di Desa Guci tidak menentu. Masih minimnya pengetahuan kelompok tani di Desa Guci mengenai perkembangan ilmu pertanian dan perikanan menjadi penyebab utama selain yang disebabkan oleh faktor-faktor lainnya seperti kurangnya pasokan air dan serangan hama.

\section{Sistem Minapadi}

Perikanan budidaya merupakan sektor penyedia sumber makanan yang sangat cepat perkembangannya. Saat ini, sektor budidaya hampir memberikan kontribusi sekitar 50\% dari total produksi perikanan dunia, dan sektor ini akan tetap menjadi tumpuan penyedia sumber makanan bagi perkembangan kebutuhan makanan di masa depan (FAO Fisheries Departement, 2006).

Produksi perikanan budidaya di Indonesia sangat menjanjikan, hal ini terbukti dengan masuknya Indonesia sebagai salah satu penghasil produksi perikanan budidaya di dunia (FAO Fisheries Departement, 2006).

Salah satu produksi perikanan budidaya di Indonesia dihasilkan dari sistem minapadi.Budidaya minapadi adalah budidaya terpadu yang meningkatkan produktivitas lahan sawah yang menghasilkan padi dan juga ikan. Budidaya minapadi juga merupakan solusi 
terbaik dalam menghadapi perubahan iklim yang ekstrim seperti saat ini. Sebagian besar ikan yang dibudidayakan dengan metode budidaya ini adalah ikan mas dan ikan nila walaupun sebenarnya tidak hanya dua komoditas tersebut yang dapat dibudidayakan dengan metode ini. Komoditas lain yang dapat dibudidayakan dengaetode ini antara lain nilem, tawes dan udang galah.

Biasanya budidaya ikan pada sistem minapadi mengandalkan tumbuhnya pakan alami yang dihasilkan dari proses pemupukan. Ikan yang dipelihara tidak diberi pakan tambahan apapun dan dipelihara secara tradisional.Walaupun menurut Ali dan Mateo (2007), pada sistem minapadimenunjukkan bahwa integrasi ikan dan padi memiliki manfaat ekonomi lebih tinggi daripada monokultur padi konvensional, namun hasil tersebut masih belum bisa maksimal. Budidaya secara intensif menjadi salah satu cara yang dapat dilakukan dalam rangka peningkatan produksi ikan.

\section{METODE PELAKSANAAN}

\section{Tahap Pelaksanaan}

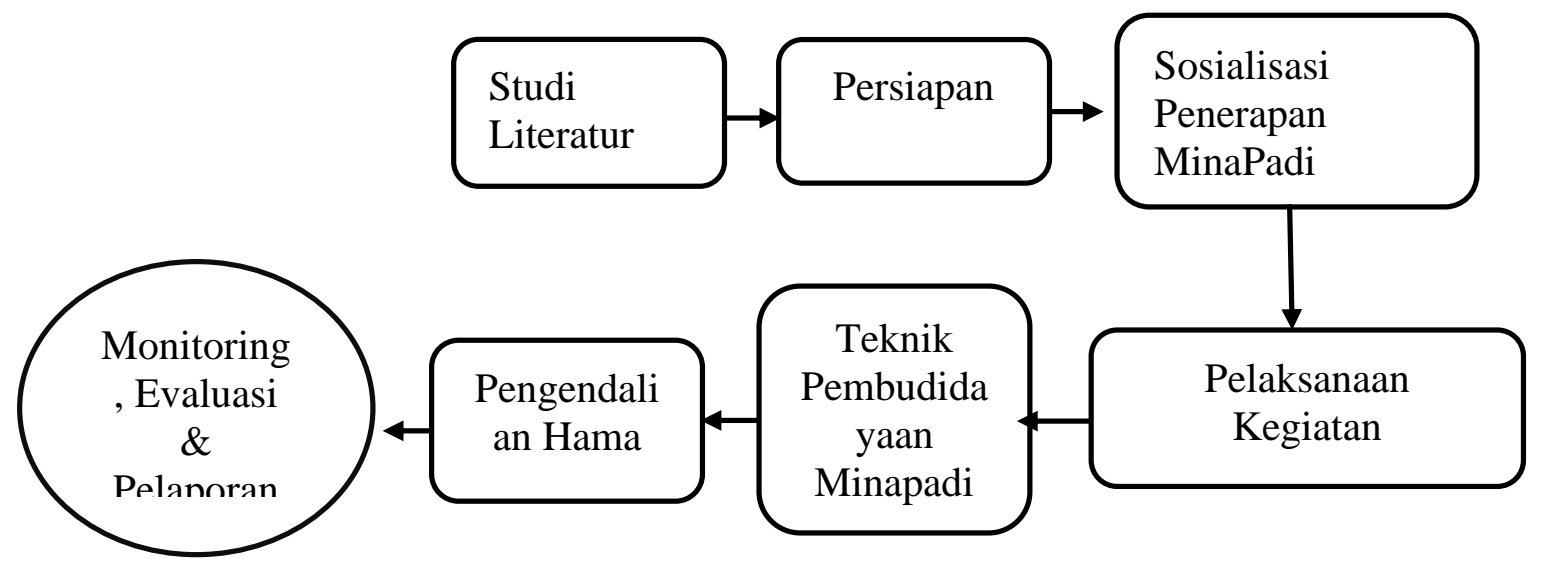

\section{Studi Literatur}

Studi literatur berisi serangkaian kegiatan pencarian dan pengkajian sumber-sumber yang relevan dan terpercaya dalam pengumpulan materi serta menjadi acuan dalam penulisan abdimas ini agar dapat dihasilkan informasi yang lengkap, terarah, dan terpercaya dalam penulisan serta memberikan variasi dalam pengembangan prototipe ini.

\section{Sosialisasi Penerapan Minapadi}

Dalam tahap sosialisasi maka tim pelaksana akan memaparkan materi tentang metode penerapan sistem Minapadi kepada Kelompok Tani di Desa Guci Kabupaten Lamongan. Kegiatan sosialisasi akan diadakan selama dua hari dengan tujuan materi dapat tersampaikan dengan baik dan tuntas mulai sebelum adanya minapadi sampai perubahan jika diterapkannya minapadi di Desa Guci Kabupaten Lamongan. 


\section{Pelaksanaan Kegiatan}

Setelah dibentuk tim pelaksana dalam tahap persiapan, langkah yang harus dijalankan oleh tim pelaksana yaitu:

\section{Identifikasi Lokasi}

Lokasi kegiatan budidaya ditetapkan berdasarkan hasil identifikasi dengan memperhatikan aspek teknis yang telah memenuhi kreteria, sebagai berikut:

a. Sawah berada dalam kawasan beririgasi teknis.

b. Lokasi terhindar dari banjir dan pencemaran;

c. Aspek daya dukung lingkungan (sosial dan keamanan) memenuhi persyaratan; dan.

d. Kesesuaian lokasi dengan penerapan teknologiyang akan dikembangkan

\section{Pemilihan Lokasi}

a. Lokasi

Area persawahan yang dapat digunakan untuk usaha minapadi adalah sawah beririgrasi teknis/non teknis atau sumber air lainnya yang memenuhi persyaratan kualitas air bududaya dan tersedia selama masa pemeliharaan. Selain faktor ketersediaan air, sawah yang digunakan juga harus memenuhi persyaratan sebagai berikut:

1) Air yang digunakan harus memenuhi persyaratan baku mutu budidaya dan sanitasi, tidak tercemar oleh cemaran fisik, kimia, dan biologis dari alam, industri pemukiman, dan pertanian serta memiliki sistem pengaturan air yang baik, sehingga air mudah untuk dikendalikan;

2) Lokasi harus bebas banjir dan sesuai dengan rencana tata ruang dan wilaya;

3) ketinggian lahan 0-700 meter diatas permukaan laut da kemiringan tanah relatif rendah;

4) Tanah yang yang dipilih berpasir dan tidak porous;

5) Pematang harus kuat untuk menahan air minimal $30 \mathrm{~cm}$ dari pelataran sawah dengan lebar minimal $50 \mathrm{~cm}$;

6) Untuk memudahkan pengangkutan dan pemasaran sebaiknya dipilih area yang dekat dengan akses jalan; dan

7) Agar pengontrolan dapat dilakukan dengan mudah sebaiknya dipilihah yang dekat dengan pemukimann penduduk.

\section{b. Sumber Air}

Sumber air untuk usaha minipadi harus cukup dan berasal dari saluran irigasi atau sumber air lainnya. Air yang digunakan harus memenuhi persyaratan baku mutu budidaya dan sanitasi, tidak tercemar oleh cemaran fisik, kimia, dan biologis dari alam, industri, pemukiman dan pertanian serta memiliki sistem pengaturan air yang baik, sehingga air mudah untuk dikendalikan. Air yang digunakan harus dapat mencukupi untuk proses produksi. 


\section{HASIL DAN PEMBAHASAN}

1) Teknik Budidaya Minapadi

Teknik budidaya minapadi untuk menghasilkan ikan konsumsi dilakukan dengan sistem tumpang sari dan palawija.

\section{2) Sistem minapadi}

Ada beberapa sistem minapadi yang dikenal saat ini yaitu sistem penyelang, sistem tumpang sari, dan sistem palawija. Dalam hal ini penulis menggunakan sistem tumpang sari.

\section{Persiapan lahan}

a) Sawah dipersiapkan sesuai dengan kebutuhan penanaman padi dan pemeliharaan ikan

b) Perbaikan saluran pemasukan dan pengeluaran serta dilengkapi dengan saringan yang terbuat dari kawat, bambu, atau jaringan.

c) Pengolahan dan pembalikan tanah;

d) Pembuatan caren keliling dengan lebar 40-100 $\mathrm{cm}$ dan caren penampung (kobokan panen) dengan ukuran $1 \times 2 \mathrm{~m}$ dan kedalaman $50-75 \mathrm{~cm}$. Dengan sistem ini caren dibuat kolam dalam dengan ukuran 0,8-1 m.

\section{Pemumukan}

Pemupukan dasar dan susulan dengan dosis $50 \%$ dari dosis pemupukan yang biasa digunakan dalam kondisi sawah masih berlumpur.

\section{Penebaran ikan}

Padat penebaran dan ukuran benih ikan disesuaikan dengan tujuan penanaman, penebaran pertama benih berukuran 5-8 cm (fingerling) dengan padat penebaran 5-10 ekor/m2 dilakukan setelah penanaman bibit padi berumur \pm 7 hari.

\section{Pemeliharaan}

Pakan tambahan berupa pelet halus dengan dosis maks.3\% dari berat bobot biomassa;

a. Monitoring kualitas air dilakukan agar kualitas air sesuai dengan standar pemeliharaan ikan

\section{Pemanenan}

b. Panen ikan 1 minggu sebelum panen padi dilakukan pada pagi atau sore hari pada saat suhu udara rendah;

c. Setelah masa pemeliharaan selama 90 hari dihasilkan ikan berukuran minimal 100 g/ekor sebanyak 30.000 - 60.000 ekor atau minimal 3-6 ton.

\section{3) Model Tanam Padi}

Model tanam padi yang digunakan untuk budidaya minapadi yaitu model kolam dalam. Modal kolam dalam adalah model tanam padi jajar legowo atau tegel yang dilengkapi parit/caren dalam dengan ukuran caren lebar minimal 1 meter dan kedalaman 0,8-1 meter. Dengan menggunakan model kolam dalam, panen padi dapat meningkat hingga $15 \%$ persatuan luas petakan sawah. 


\section{4) Pemberian Pakan}

Dalam usaha budidaya, pakan merupakan komponen biaya terbesar selama pemeliharaan yaitu berkisar antara 80-85\%. Kebutuhan pakan yang berkualitas sangat berpengaruh bagi pertumbuhan ikan. Untuk mendapatkan produk ikan yang memenuhi jaminan mutu dan keamanan pangan, maka pakan ikan yang digunakan harus memiliki nomor pendaftaran/sertifikat yang dikeluarkan oleh Direktur Jenderal Perikanan Budidaya atau surat jaminan dari instansi yang berkompeten.

Pemberian pakan disebarkan secara perlahan untuk memberikan waktu bagi ikan memakan pelet dan pembudidaya dapat melihat kebiasaan makan pada ikan ini. Jumlah pakan yang diberikan sebanyak maksimal 3\% dari total biomassa.

Penentuan jumlah pakan dilakukan dengan cara sampling yaitu mengambil beberapa ekor ikan dan menimbang bobotnya, sehingga dapat diduga bobot total (biomass) sebagai berikut :

Bobot Total $=$ rata - rata bobot iklan sampling $\times$ jumlah ikan total

\section{5) Panen}

Ikan dapat dipanen dalam waktu pemeliharaan 90-100 hari atau lebih sesuai ukuran yang dibutuhkan oleh konsumem. Biasanya ikan konsumsi dapat dijual setelah mencapai ukuran minimal 100 gram/ekor, tetapi semakin besar ukuran ikan harganya juga semakin tinggi. Teknik memanen yang sangat mudah dilakukan dengan cara mengeringkan sawah baik beberapa atau menyeluruh. Jika ingin memanen seluruh ikan, maka petakan sawah dapat dikeringkan seluruhnya. Pada waktu pemanenan sebaiknya dimasukkan air segar kedalam petakan sawah dan pemanenan sebaiknya dilakukan pada pagi atau sore hari. Air dibuang melewati saluran pembuangan di dalam sawah hingga seluruh ikan dapat mengumpul di dalam kobakan dan selanjutnya ditangkap menggunakan serok.

\section{KESIMPULAN DAN SARAN}

Tahap sosialisasi dilaksanakan di tempat mitra yaitu Kelompok Tani sebagai penghasil beras organik di Desa Guci Kabupaten Lamongan. Sosialisasi tersebut akan dilakukan secara intensif kepada beliau mulai dari instalasi alat, pengoperasian alat dan pemeliharaan alat. Selain itu strategi manajemen pemasaran juga disosialisasikan kepada Kelompok Tani mengingat beras organik akan dipasarkan secara meluas. Setelah kegiatan tersebut dilaksanakan, perlu diadakan monitoring untuk memantau kemajuan dari kegiatan yang telah dilakukan baik dari segi teknologi pengemasan maupun pemasaran.

Evaluasi bertujuan untuk membandingkan antara rencana dengan realisasi kegiatan untuk menjadi rekomendasi yang akan datang. Evaluasi juga bertujuan untuk melihat dampak sebelum dan sesudah penerapan budidaya minapadi. Kegiatan evaluasi dapat dilakukan dengan menganalisa relevansi, efektifitas dan dampak dari hasil pelaksanaan kegiatan terhadap tujuan, sasaran, indikator keberhasilan yang diharapkan serta melihat sejauh mana permasalahan yang dihadapi sebagai bahan acuan dan referensi untuk menentukan alternatif solusi dan rencana tindak lanjut. Evaluasi pelaksanaan kegiatan budidaya minapadi tersebut mencakup:

a. Penerapan teknologi budidaya anjuran di lokasi pelaksaan kegiatan;

b. Peningkatan produksi dan produktifitas budidaya ikan setelah melalui input teknologi; 
c. Dampak pelaksanaan kegiatan budidaya minapadi terhadap peningkatan pendapatan Kelompok pembudidaya minapadi serta keberlanjutan sistim usaha budidaya di tingkat Kelompok Minapadi; dan

d. penyebarluasan penerapan teknologi anjuran pada kawasan sekitarnya.

\section{DAFTAR PUSTAKA}

Chen W. (2010) Clean Coal Technology Development in China. Energy Policy

Cahyanti, Wahyulia dan rekan. 2014. Produksi Ikan Unggul Di Lahan Minapadi Secara Intensif. Bandung: Balai Penelitian dan Pengembangan Budidaya Air Tawar.

Derektorat Kemahasiswaan Direktorat Jendral Pembelajaran Dan Kemahasiswaan. 2018. Pedoman PKM Tahun 2018. Jakarta: Kementrian Riset, Teknologi, Dan Pendidikan Tinggi.

Direktorat Jenderal Perikanan Budidaya Direktorat Produksi Dan Usaha Budidaya.2016. Petunjuk Teknis Sarana Budidaya Minapadi. Jakarta: Kementrian Kelautan Dan Perikanan Republik Indonesia.

Mahardika, Singgih Nugroho dan rekan. 2014. Vaporice (Vacuum Packing On Organic Rice): Penerapan Teknologi Vacuum Packing Dalam Pengemasan Beras Organik Di Kelompok Tani Kurnia Indah Desa Peniwen Kabupaten Malang. Malang: Universitas Brawijaya. 